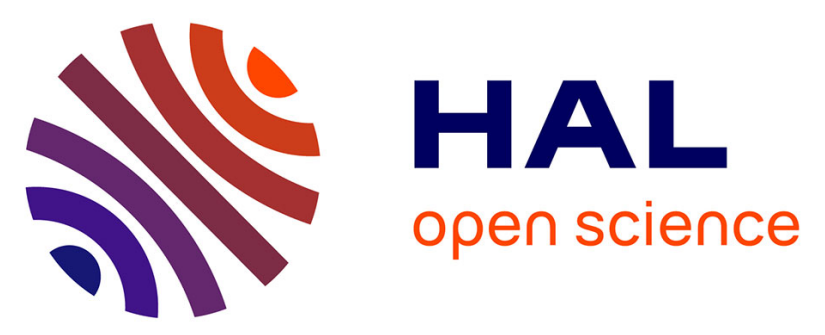

\title{
Depositional environment of a Kimmeridgian carbonate 'black band' (Akkuyu Formation, south-western Turkey)
}

François Baudin, Nicolas Tribovillard, Fatima Laggoun-Défarge, E. Lichtfouse, Olivier Monod, Silvia Gardin

\section{- To cite this version:}

François Baudin, Nicolas Tribovillard, Fatima Laggoun-Défarge, E. Lichtfouse, Olivier Monod, et al.. Depositional environment of a Kimmeridgian carbonate 'black band' (Akkuyu Formation, southwestern Turkey). Sedimentology, 1999, 46 (4), pp.589-602. 10.1046/j.1365-3091.1999.00226.x . hal00139358

\section{HAL Id: hal-00139358 \\ https://hal-insu.archives-ouvertes.fr/hal-00139358}

Submitted on 2 May 2007

HAL is a multi-disciplinary open access archive for the deposit and dissemination of scientific research documents, whether they are published or not. The documents may come from teaching and research institutions in France or abroad, or from public or private research centers.
L'archive ouverte pluridisciplinaire HAL, est destinée au dépôt et à la diffusion de documents scientifiques de niveau recherche, publiés ou non, émanant des établissements d'enseignement et de recherche français ou étrangers, des laboratoires publics ou privés. 


\title{
Depositional environment of a Kimmeridgian carbonate 'black band' (Akkuyu Formation, south-western Turkey)
}

François Baudin, Nicolas Tribovillard, Fatima Laggoun-Défarge, Eric Lichtfouse, Olivier Monod, Silvia Gardin

${ }^{1}$ CNRS-ESA 7073 et FR 32, Département de Géologie Sédimentaire, Université P. et M. Curie, case postale 117, 4 place Jussieu, 75252 Paris Cedex 05, France (E-mail frbaudin@ccr.jussieu.fr), ${ }^{2}$ Laboratoire de Géochimie des Roches Sédimentaires et CNRSURA 723, Université Paris-Sud, Bat. 504, 91405 Orsay Cedex, France, ${ }^{3}$ CNRS-UMR 6531 et FR 09, Université d'Orléans, BP 6759, 45067 Orléans-La Source Cedex 2, France, ${ }^{4}$ Laboratoire de Biogéochimie isotopique, Université P. et M. Curie, 75252 Paris Cedex 05, France, ${ }^{5}$ CNRS-UMR 6530 et FR 09, Université d'Orléans, BP 6759, 45067 Orléans-La Source Cedex 2, France

\begin{abstract}
The Upper Jurassic Akkuyu Formation of south-western Turkey consists of pale-coloured carbonate facies, but includes a peculiar 'black band' at its base. In order to characterize the depositional environment of this level, a sedimentological, organic and inorganic geochemical study was performed on 30 samples. Three units are distinguished. Unit 1 consists of black marlstones, very rich in organic carbon $(22-30 \%)$ with HI (hydrogen index) values around 600. The organic matter is an amorphous homogeneous material even at nanoscopic scale. This unit is also characterized by a very high concentration of $\mathrm{V}$ ( $>1000$ p.p.m.) and a $\delta^{13} \mathrm{C}_{\text {org }}$ value around $-26.5 \%$. Unit 2 shows thin-bedded black limestones with chert layers. Its organic content varies from $2 \%$ to $6 \%$. As in unit 1 , the HI values are uniformly high (600), and gas chromatography shows a high quantity of hopanes. The $\mathrm{V}$ concentration is also high $(\approx 400$ p.p.m.). The unit has a high $\mathrm{Sr} / \mathrm{Ca}$ ratio, an organic carbon isotopic ratio close to $-28.7 \%$ and diffuse, nanoscopically amorphous organic material that is closely associated with pyrite. Unit 3 corresponds to the white limestones overlying the 'black band'. This calcitic facies is almost devoid of organic carbon $(<0 \cdot 1 \%)$. The $\delta^{13} \mathrm{C}_{\text {org }}$ values are similar to those of unit $1(-25 \cdot 5 \%$ to $-26 \%)$. Deposition occurred in a basinal environment surrounded by a carbonate platform. Primary productivity was high but not exceptional; terrestrial organic inputs were scarce. Bottom waters were probably euxinic during the deposition of unit 1 . The presence of both hopane-rich and sulphur-rich nanoscopically amorphous organic matter may be the result of strong sulphate-reducing bacterial activity. Coupled with low amounts of iron, this led to intense vulcanization of the organic matter and thus good preservation. With the onset of unit 2 deposition, environmental conditions became less extreme, perhaps because of cooler water temperatures. Finally, the depositional conditions became oxic, leading to the accumulation of pale-coloured organic-poor limestones of unit 3.
\end{abstract}

\section{Introduction}

Organic geochemical studies of carbonate rocks have demonstrated their importance in generating hydrocarbons ( Jones, 1984; Oehler, 1984; Palacas et al., 1984; Claypool \& Mancini, 1989; Taguchi \& Mori, 1992). Most of these studies, however, focused on the geochemical characterization of the kerogen and the generation of hydrocarbons. Our objective is to understand the factors contributing to the development of carbonate source rocks, by studying the origin of organic matter and conditions that favour its preservation and distribution within sediments, using a multidisciplinary approach (sedimentology, organic 
petrography and geochemistry). The case study examined here is a carbonate 'black band', a conspicuous horizon occurring at the boundary between lower and upper Kimmeridgian within the Upper Jurassic-Lower Cretaceous Akkuyu Formation of SW Turkey.

\section{Geological Setting}

The central part of the western Taurus Mountains in south-western Turkey (Fig. 1) comprises a thick succession of pale-coloured carbonates of Mesozoic age overlain by Eocene flysch. South of Lake Beysehir, the pale-coloured carbonate facies includes a peculiar 'black band', described as bituminous by Blumenthal (1951). Martin (1969) defined this level as part of the Akkuyu Formation, a conspicuous Upper Jurassic to Lower Cretaceous pelagic formation within the shallow-marine carbonate platform facies. In the type locality, the entire formation is $\approx 200 \mathrm{~m}$ thick and can be subdivided into three informal members:

1 The lower member (60-70 m thick) consists of thinly bedded white to beige micritic limestones containing pelagic fauna and plant remains. The 'black band' appears about $10 \mathrm{~m}$ from the base and is an excellent marker bed ( Monod, 1977; Gutnic et al., 1979). This level is $3.5-5.0 \mathrm{~m}$ thick and contains numerous ammonites (Enay et al., 1971), aptychi, radiolaria, thin-shelled flat-valved bivalves, fish debris ( Forey et al., 1985) and plant remains ( Corsin \& Martin, 1969). At the type locality, the rich ammonite assemblage of the 'black band' provides confident data pointing to a Kimmeridgian age and, more precisely, to the boundary between lower and upper Kimmeridgian ( Enay et al., 1971).

2 The middle member ( $130 \mathrm{~m}$ thick) consists of well-bedded white micritic limestones and brownish cherty limestones. At the base, ammonites indicate a Tithonian age, whereas the age of the top is not clearly established.

3 The upper member, corresponding to the uppermost $10 \mathrm{~m}$ of the Akkuyu Formation, consists of thicker beds of calcarenitic limestone. Reworked calpionellids indicate a Berriasian to early Valanginian age.

The Akkuyu Formation exhibits noticeable regional variation in facies, thickness and age ( Monod, 1977; Gutnic et al., 1979), summarized in Fig. 2. Whereas it is mainly composed of white pelagic limestones in the type area, it becomes entirely black and dolomitic in the northeastern part of the basin. In parallel with this colour change, the faunal assemblage becomes more restricted and shallower north-eastwards, where layers with small benthic bivalves (Nanogyra sp.) alternate with pelagic fauna. These lateral variations suggest an environmental change from open conditions in the south-western part of the basin to restricted and shallowwater conditions further to the north-east. The thickness varies from $200 \mathrm{~m}$ in the type area to $30 \mathrm{~m}$ in the north-east ( Monod, 1977). Although tectonic slicing within the Akkuyu Formation is conspicuous at some localities, the 'black band' is recognized in most outcrops of the lower part of the formation in the south-western part of the basin. The stratigraphic extent of the formation is also variable; the base ranges from upper Oxfordian in the southwestern part of the basin to lower Tithonian in the north-east ( Enay et al., 1971).

\section{Materials and Methods}

Thirty closely spaced samples of the black horizon were collected from the basal part of the type section. Care was taken to avoid weathered material. Thin-section petrography was performed on each sample, and selected samples were studied using scanning electron microscopy (SEM). Calcium carbonate contents were determined using the carbonate bomb 
technique. Mineralogical assemblages were determined using X-ray diffraction (XRD), on both bulk rock and carbonate-free clay fractions $(<2 \mu \mathrm{m})$. Major and trace elements were determined using SEM-EDS (energy dispersive spectrometry) analysis of pressed powders or inductively coupled plasma-atomic emission spectrometry (ICP-AES). Total organic carbon (TOC) content was determined using both LECO C/S 125 apparatus and Rock-Eval II ( Espitaliéet al., 1985a, b, 1986). Standard notations are used: $S_{1}$ and $S_{2}$ in $m g$ hydrocarbons (HC) per $\mathrm{g}$ of rock; $T_{\max }$ expressed in ${ }^{\circ} \mathrm{C}$; total organic carbon (TOC) content in weight percentage; hydrogen index (HI) and oxygen index (OI) in $\mathrm{mg} \mathrm{HC}$ and $\mathrm{CO}_{2}$ per $\mathrm{g}$ of $\mathrm{TOC}$ respectively. Sulphur contents were measured on organic matter with the LECO. Nine wholerock samples were extracted using chloroform-methanol $(3: 1 \mathrm{v} / \mathrm{v})$, and the alkane fraction was analysed by gas chromatography (GC); the detailed procedure is given in Lichtfouse et al. (1994). Kerogens were concentrated by HF-HCl maceration from the extracted samples and analysed using Rock-Eval pyrolysis. Isotopic analyses of the kerogen concentrates were performed on a Carlo-Erba CHN analyser coupled with a VG-Sira X isotope-ratio mass spectrometer. Palynofacies was used in order to characterize and quantify the different organic constituents. Five of the kerogen concentrates, previously fixed in osmium tetroxide, were observed by transmission electron microscopy (TEM) on ultrathin sections $(30-50 \mathrm{~nm}$ thick) using a STEM JEOL $100 \mathrm{CX}$ instrument. Elemental microanalyses were obtained using an energy-dispersive X-ray (EDX) spectrometer fitted to the TEM.

\section{Results}

\section{Lithofacies and source of carbonate}

Three lithofacies units are distinguished on the basis of outcrop and microfacies examination (Fig. 3):

1 Poorly exposed in the type section, this basal unit $(1.5 \mathrm{~m})$ consists of black marlstones with a low density (Fig. 3A). In thin section, this marlstone appears as an orange to brown, poorly stratified mudstone with fish scales, ostracods and rare radiolaria (Fig. 3B). Fine quartz grains $(20 \mu \mathrm{m})$ are present in low amounts $(<1 \%$ visual relative abundance).

2 The middle part is a $3 \cdot 65-\mathrm{m}$-thick unit of well-bedded black packstone containing six thin black chert layers (Fig. 3C). Macrofossils (ammonites, Posidonia and Aulacomyella, fish remains and plant fragments) are abundant. Lamination is obvious, and only some paler layers (IC, IIIB1, IVA and IVD; Fig. 4) show a rough grading of the clasts. The rock is fractured and locally shows oil seeps. In thin section, the samples appear as a finely laminated micropackstone with abundant radiolaria, planktonic foraminifera, thin-shelled flat-valved bivalves and fish scales (Fig. $\underline{3 D})$. Small faecal pellet $(100 \mu \mathrm{m})$ accumulations are visible (Fig. 3E). Radiolarian tests that are not occupied by sparry calcite are commonly filled with oil. Except for the Posidonia and Aulacomyella, no trace of benthic life has been found in this unit. Apart from clay minerals and drifted plant remains, almost no evidence of land-derived material, such as detrital quartz, is found. SEM observations indicate that calcareous nanofossils are an important source of carbonate in this facies (Fig. $\underline{3 F}$ ).

3 Above the 'black band', limestones present the same lithofacies as the thinly bedded limestone from unit 2, but become pale-coloured and contain common fine carbonate turbiditic layers (Fig. $3 \mathrm{G}$ ). It is noteworthy that the colour change is sharp but that the fauna remains the same in both facies. 
These data suggest deposition in moderately deep water, in a protected and low-energy environment with restricted bottom circulation, at least during 'black band' deposition.

\section{Sediment composition}

The three units show variable proportions of calcium carbonate and organic matter (Table 1 , Fig. 4). The black marlstone lithofacies contains from $40 \%$ to $60 \% \mathrm{CaCO}_{3}$ and between $22 \%$ and $30 \%$ of total organic carbon. The black limestone lithofacies contains between $60 \%$ and $90 \% \mathrm{CaCO}_{3}$, whereas organic carbon percentages range between $2 \cdot 5 \%$ and $6 \%$. As expected, the $\mathrm{CaCO}_{3}$ percentages of white limestones are higher than $98 \%$, whereas the organic content is below $0 \cdot 1 \%$ (Table 1). In these levels, the carbonate is almost pure: the $\mathrm{Al}, \mathrm{Fe}$ and $\mathrm{K}$ contents do not exceed $0 \cdot 18 \%$ (Table 2 ).

Land-derived detrital elements are scarce. The Al contents are low (0.01-0.93 wt $\%$; Table 2$)$. For units 1 and 2, Al contents are of the same order of magnitude as those for average carbonate sedimentary rocks or pelagic carbonates (Turekian \& Wedepohl, 1961) but, for unit 3 , the $\mathrm{Al}$ content is much lower $(0 \cdot 01-0 \cdot 18 \mathrm{wt} \%)$. The black limestones contain little clay minerals and quartz grains but, when present, clays are represented by kaolinite and illite/smectite mixed-layer minerals. In the latter case, the illite layer abundance exceeds $90 \%$. Relatively consistent $\mathrm{K} / \mathrm{Al}$ and $\mathrm{Fe} / \mathrm{Al}$ ratios confirm the homogeneity of the terrestrial input.

As very few aluminosilicates were observed in these carbonates, it is probable that iron is mostly present as pyrite. Based on this assumption, the pyrite-bound part of the $\mathrm{S}$ content is calculated as follows: $\mathrm{S}_{\text {pyrite }}=\mathrm{Fe} / 0 \cdot 87$ (note that this is a maximum value, as all the iron is taken into account). Hence, the proportion of organic-bound sulphur is calculated as: $\mathrm{S}_{\text {org }}=\mathrm{S}_{\text {total }}-\mathrm{S}_{\text {pyrite. }}$. Thus, the organic-bound part of the $\mathrm{S}$ content represents $70-90 \%$ of the total $\mathrm{S}$ content.

\section{Source of organic matter in the 'black band'}

Cherty horizons excepted, the hydrogen index (HI) values of both units 1 and 2 are similar, with a mean value about $590 \mathrm{mg} \mathrm{HC} / \mathrm{g}$ TOC (Fig. 4), whereas oxygen index (OI) values remain low ( $<20 \mathrm{mg} \mathrm{CO}_{2} / \mathrm{g}$ TOC) with an average around 10 (Table 1). Owing to the narrow range of the $T_{\max }$ values $\left(434-436{ }^{\circ} \mathrm{C}\right.$; Baudin et al., 1994; Baudin \& Monod, 1996), the source of organic matter can be estimated on the basis of HI and OI values as a Type II (sensu Tissot \& Welte, 1984).

Gas chromatograms from units 1 and 2 show a bimodal distribution (Fig. 4). The first mode occurs at $\mathrm{C}_{14}-\mathrm{C}_{18}$ with a slight predominance of even-numbered $n$-alkanes and a maximum at $\mathrm{C}_{16}$, suggesting a phytoplanktonic origin. The second mode corresponds to hopanes and, in smaller quantity, to steranes. The hopane/n-alkane ratio is unusually high $(64-67 \%)$ and suggests high microbial activity during early diagenesis. The similarity of GC traces of samples from units 1 and 2 indicates a uniform source of the organic matter in the black band'. The chromatogram of pale-coloured facies from unit 3 contrasts sharply. The $n$-alkanes present a strong even-numbered predominance in the range of $\mathrm{C}_{14}-\mathrm{C}_{18}$ (Fig. 4), suggesting a phytoplanktonic origin of the organic matter. The relative concentration of hopanes in unit 3 is strikingly smaller than that for units 1 and 2, suggesting either a lower input of bacteria or oxidative degradation.

The palynological residues are mainly composed of amorphous organic matter (AOM), which represents about $90-95 \%$ of the organic fractions. A low contribution of land-derived organic matter is represented by rare woody debris. Two types of AOM were identified according to 
their colour and texture: orange and homogeneous flakes of AOM (Fig. ㄷA); and brownish and granular AOM (Fig. $\underline{5}$ C). The first type of AOM seems to be mainly present in unit 1, while the second dominates in unit 2. TEM observations show that the orange AOM corresponds to massive and homogeneous gel-like material devoid of any apparent biological structures, even at high magnification (Fig. 5B). The brown AOM comprises a diffuse nanoscopically amorphous material, which is closely associated with mineral 'ghosts' and forms a continuous organic network (Fig. 5D). Such material is often associated with pyrite crystals (Fig. 5D), as indicated by EDX analysis, while the homogeneous AOM contains framboidal pyrite. In situ analysis with the EDX spectrometer fitted to the TEM showed that both AOM types are characterized by a high sulphur content.

\section{Trace elements and environmental conditions}

The three units present a clear discrepancy in the distribution of trace-element abundance (Table 2). To normalize the element contents, two methods are possible: Al normalization (element/Al ratio) or carbonate-free basis normalization [element abundance $\left.\times 100 /\left(100-\mathrm{CaCO}_{3}\right)\right]$. In the present case, low to very low $\mathrm{Al}$ abundances (down to $0.01 \%$ in unit 3 ) introduce a bias in the element/Al ratios, which reach artificially very high values, as is the case, for instance, for the samples from unit 3 that have Al contents mostly below $0 \cdot 1 \%$ (Table 2 ). This calculation bias particularly affects metals that are not carried by the aluminosilicate fraction alone, but are also or mainly present in phosphates $(\mathrm{P})$, sulphides (e.g. $\mathrm{Ni}, \mathrm{Cu}, \mathrm{Mo}$ ) or other carrier phases (Ba). Consequently, a carbonate-free basis normalization (CFB) was also performed. Table 2 lists selected results, plus the values for the average carbonate sedimentary rocks ( Turekian \& Wedepohl, 1961) for which the Al and CFB normalizations were calculated. In spite of the high organic carbon contents of our samples, the average carbonate sedimentary rock values were chosen instead of those of average shale, because the $\mathrm{Al}$ and $\mathrm{Ca}$ contents of the samples studied here are closer to the former.

The element contents and ratios show that units 1 and 2 ('black band') are highly enriched in $\mathrm{V}, \mathrm{Mo}, \mathrm{Cr}, \mathrm{Ni}, \mathrm{Cu}$ and $\mathrm{Ba}$, while they are strongly depleted in $\mathrm{Mn}$ and, to a lesser degree, $\mathrm{P}$, relative to both average values and unit 3. Higher $\mathrm{V}$, Mo and $\mathrm{Cr}$ abundances in units 1 and 2 compared with unit 3 may be accounted for by strongly reducing conditions during the deposition and burial of units 1 and 2 (Breit \& Wanty, 1991; Wanty \& Goldhaber, 1992; Calvert \& Pedersen, 1993; Crusius et al., 1996). Phosphorus is a nutrient, and barium behaves like one. Both elements may be regarded as productivity proxies, and an extensive literature is devoted to them (e.g. Schmitz, 1987; Ingall \& Van Cappellen, 1990; Dymond et al., 1992; Gingele \& Dahmke, 1994; McManus et al., 1994; Van Cappellen \& Ingall, 1994). Phosphorus and, to a lesser degree, barium may both be released by sediments under reducing conditions ( Kumar et al., 1996). Consequently, as units 1 and 2 endured reducing conditions during deposition and/or diagenesis, part of their $\mathrm{P}$ and $\mathrm{Ba}$ must have escaped back to the water column. However, unit 3 did not experience reducing environmental conditions as stated above. Thus, its relative depletion in $\mathrm{P}$ and $\mathrm{Ba}$ must not result from synsedimentary or diagenetic remobilization, but may instead reflect a lower productivity of surface waters. Lastly, unit 2 shows the highest $\mathrm{Sr}$ content and $\mathrm{Sr} / \mathrm{Ca}$ values, and unit 3 the lowest (Fig. 4, Table 2). 


\section{Carbon isotopes}

$\delta^{13} \mathrm{C}$ values for organic matter are summarized in Table 1 and shown in Fig. 4; excluding AK129, they vary from $-26 \cdot 5 \%$ to $-28 \cdot 5 \%$, which is in the range of isotopic ratios reported for most of the amorphous kerogen from pre-Neogene marine sedimentary rocks (Lewan, 1986). The black limestones from unit 2 are isotopically lighter (2\%o less) than those from units 1 and 3. This difference may result from variations in plankton species, atmospheric $\mathrm{CO}_{2}$ concentration, global seawater $\delta^{13} \mathrm{C}$, selective preservation or $\mathrm{CO}_{2}$ source.

As mentioned above, the main planktonic biomass of the Akkuyu 'black band' seems to be coccolithophorids. In spite of the lack of species determination, it remains difficult to invoke variation in the primary producers to explain the 2\%o shift between units 1 and 2 . Changes in the atmospheric $\mathrm{CO}_{2}$ concentration or seawater $\delta^{13} \mathrm{C}$ are also unlikely at that time, mainly because such changes should also be recorded in the isotopic ratio of carbonate, which is not the case according to recently published curves ( Weissert \& Mohr, 1996; Riboulleau et al., 1998). Selective preservation of organic matter is more likely, although GC data show the same fingerprint, and palynofacies do not present evidence of particular structures related to selective preservation, such as ultralaminae (Raynaud et al., 1988).

The most reasonable explanation for the observed differences in $\delta^{13} \mathrm{C}_{\text {org }}$ is variation in the $\delta^{13} \mathrm{C}$ value of the dissolved $\mathrm{CO}_{2}$ metabolized by phytoplankton during photosynthesis. Anaerobic and aerobic bacterial decomposition of organic matter in a water column or within the sediment may provide a source of $\mathrm{CO}_{2}$ depleted in ${ }^{13} \mathrm{C}$ (Deuser, 1970; Lewan, 1986). The degradation of organic matter during the deposition of unit 1 probably led to the progressive diffusion of isotopically lighter organic-derived $\mathrm{CO}_{2}$ into the stagnant waters of the Akkuyu basin. This change is recorded during the deposition of unit 2, whereas with the onset of unit 3 , the $\delta^{13} \mathrm{C}$ value of $\mathrm{CO}_{2}$ returned to the atmospheric ratio. It should be noted that seawater temperature also controls the isotopic fractionation by phytoplankton. Some present-day species, living below $15^{\circ} \mathrm{C}$, may become significantly enriched in ${ }^{12} \mathrm{C}$ ( Lewan, 1986). Such an explanation is not inconsistent with the previous one and is in good agreement with the variation in the $\mathrm{Sr} / \mathrm{Ca}$ ratio in unit 2, interpreted as the result of a small decrease in sea-surface temperature (see below).

\section{Discussion}

\section{Depositional environment}

Both petrographic and palynofacies observations indicate very low amounts of land-derived organic matter. The microfacies and XRD data show only a minor proportion of terrigenous debris (no silt-size particles, only a very poorly represented clay mineral phase, not always present). A relatively constant K/Al ratio (Table 2) indicates little clay mineral variation. The uniformity of the $\mathrm{Fe} / \mathrm{Al}$ ratio in units 1 and 2, together with the steady $\mathrm{Th} / \mathrm{Al}$ ratio, also illustrates the homogeneity of the terrestrial inputs and suggests very distant sources. The sediment resulted largely from the rain of autochthonous biogenic carbonate and organic particles (chiefly coccoliths and algal organic matter).

Trace-element contents reflect an evolution of redox conditions from unit 1 to unit 3 . The most reducing conditions of deposition were recorded at the water-sediment interface or within the upper part of the sedimentary column during the deposition of unit 1 . They were reducing, but less so, during unit 2 deposition, and no longer reducing during the deposition of unit 3. This sequence of redox conditions is accompanied by a decrease in the organic matter content of the sediments. The evolution of redox conditions and organic matter 
accumulation are reflected in the $\mathrm{Ni}$ and, to a lesser extent, the $\mathrm{Cu}$ contents, which decline upwards (Table 2).

The organic content of the 'black band' of the Akkuyu Formation reflects the evolution of the depositional environment, from restricted conditions to ventilated ones. Such a progressive replenishment of dissolved oxygen can be triggered by various mechanisms:

1A decrease in surface productivity of phytoplankton would lower the downward flux of organic matter. Less organic decay would lead in turn to lower oxygen consumption in bottom waters. This would allow oxygen to be replenished.

2 The nature of productivity may have evolved with time; during unit 1 deposition, productivity may have corresponded to more abundant organic-walled plankton and less abundant coccolithophorids (which could also explain the lower $\mathrm{CaCO}_{3}$ content of these beds).

3 Other possible methods, not exclusive of those above, may reside in the evolution of watermass circulation affecting the basin, possibly resulting from changes in regional circulation, related to a platform shallowing, sea-level fluctuation or tectonic movements.

The high Sr content of sediments from unit 2 contrasts strongly with those from units 1 and 3 (Table 2). Many factors influence the $\mathrm{Sr}$ content or the $\mathrm{Sr} / \mathrm{Ca}$ ratio of biogenic carbonates ( Morse \& Mackenzie, 1990), including the type of dominant carbonate-secreting organisms forming the sediment (vital effects), the temperature of the sea water in which the carbonate particles formed, the Sr content of the sea water, plus diagenetic effects. Shifts in the $\mathrm{Sr} / \mathrm{Ca}$ ratio of pelagic carbonates may also be caused by migration of the main 'carbonate factories' (Renard, 1986), as in the case of carbonate platform flooding.

The main source of carbonate was coccolithophorids. Even if we cannot exclude possible population variations affecting the flux between units 1 to 3 , the influence of vital effects upon the Sr content may be ruled out. It is also unlikely that diagenesis would produce the extreme $\mathrm{Sr} / \mathrm{Ca}$ ratio of unit 2, relative to units 1 and 3. We have no petrographic (from thinsection observation or XRD data) or geochemical evidence that indicates that the sediments of unit 2 evolved differently during diagenesis compared with the other two units, thereby doubling the $\mathrm{Sr} / \mathrm{Ca}$ ratio. Strontium enrichment could have resulted from an increase in the $\mathrm{Sr}$ content of the ocean reservoir but, to our knowledge, no comparable short-term excursion has ever been reported.

It is concluded that the most probable mechanism to account for the observed Sr variation seems to be a temporary drop in seawater temperature, which would have led to an increase in the $\mathrm{Sr} / \mathrm{Ca}$ ratio of biogenic carbonates (Morse \& Mackenzie, 1990) in unit 2. No information is available from the literature about the extent of the decrease in temperature necessary to account for the approximate doubling in the $\mathrm{Sr} / \mathrm{Ca}$ ratio for sediments as old as Jurassic. Nevertheless, such a decrease also seems to be indicated by the $\delta^{13} \mathrm{C}$ value distribution.

Such a short-term cooling could be caused by several factors: (1) the onset of upwelling circulation, which is dubious in such an environment; (2) shallowing, which would imply more circulation and less stable water stratification; (3) a modification of regional current patterns, which would have had the same effect. 
For the moment, more research is needed to propose a satisfactory explanation.

\section{Vulcanization of organic matter}

Samples that are rich in organic matter are also rich in sulphur, especially those from unit 1 , which contain between 3.33 and $5.32 \mathrm{wt} \%$ of bulk sulphur (Fig. 6, Table 1). With the assumption that all iron is present as pyrite (see above), the proportion of the organic-bound fraction may be calculated as ranging between $71 \%$ and $89 \%$ for unit 1 . Recent papers ( Boussafir et al., 1994, 1995; Permanyer et al., 1994; Gelin et al., 1995; Mongenot et al., 1997) suggest that such an organic-S enrichment coupled with a nanoscopically amorphous organic matter is characteristic of vulcanized organic matter. Natural vulcanization is an early diagenetic process leading to sulphur enrichment of aliphatic organic matter (Sinninghe Damstéet al., 1989; Tegelaar et al., 1989); inter- or intramolecular incorporation of reduced inorganic sulphur species into low-molecular-weight functionalized lipids results in the formation of high-molecular-weight sedimentary organic matter. This abiogenic sulphur incorporation produces organic sulphur compounds that become more stable under geological conditions than their precursors (Sinninghe Damstéet al., 1989; de Leeuw \& Sinninghe Damsté, 1990).

Samples from unit 2 are also rich in organic matter, but their organic sulphur content is less (50-80\% of total S). At the nanoscopic scale, the AOM shows a more diffuse texture (Fig. 5D). So, it may be inferred that the AOM trapped within the sediments of unit 2 did not go through the vulcanization process, or that this process was less complete than in the underlying unit. Various causes may be put forward to account for this: natural vulcanization may have been hampered either because of environmental factors or because the nature of the organic matter was unsuitable; the deposition of the carbonate layers of unit 3 was not accompanied by any noticeable storage of marine organic matter and, consequently, there was no question of vulcanization.

The iron content is very low in all three units, decreasing from unit 1 to unit 3 in which it is almost absent $(<0 \cdot 1 \%)$. Consequently, iron (a major trap for $\mathrm{H}_{2} \mathrm{~S} / \mathrm{HS}-$ ) cannot be invoked to account for the observed variations in vulcanization intensity. Moreover, no differences in the biological nature of the primary production have been detected. As a consequence, the reason(s) why organic matter was or was not completely vulcanized could relate to variations in the accumulation rate of organic matter, which is related to possible shifts in the bulk sedimentation rate or redox conditions affecting the entire water column, or at least its lowest part. Perhaps the organic matter was already too degraded to be completely vulcanized within the sediments when it reached the floor during unit 2 and 3 deposition; alternatively, the water column could have experienced euxinic conditions during unit 1 deposition. This would have permitted the vulcanization processes to begin before particle settling, and it would therefore have occurred above the water-sediment interface. Hence, vulcanization could have operated extensively during the deposition of unit 1 , while the water column was stratified. Thus, the environmental conditions could have evolved from the reducing environment of unit 1 to the fully oxygenated environment of unit 3 (totally unfavourable to organic matter storage), via intermediate conditions during the deposition of unit 2. Unit 2 was still favourable to organic matter storage, but less favourable to complete vulcanization because the process was occurring only below the water-sediment interface. One further explanation may be suggested: the reason for strong vulcanization in unit 1 may partly be slower deposition, and thus longer residence time in the surficial sediment in which sulphide concentrations were probably greatest (highest sulphate reduction rates), as well as lower dilution of organic matter. 


\section{Conclusions}

Our data permit the reconstruction of the environmental changes during the deposition of an organic-rich 'black band' in the Upper Jurassic of the western Taurus:

1The depositional setting was a moderately deep protected environment on a carbonate platform. The organic matter was particularly well preserved in anoxic, perhaps even euxinic, bottom conditions during the deposition of unit 1 . Sulphate reduction, coupled with the low availability of iron, led to intense vulcanization of the organic matter. The result is an exceptionally organic-rich level $(25-35 \%$ TOC) characterized by gelatinous amorphous organic matter, rich in organic-S and hopanes.

2With the onset of unit 2, conditions were less reducing, perhaps because of a change in the primary production or a climatic (cooling) effect. The organic matter was still vulcanized but stored in lower quantities (2-6\% TOC).

3Finally, the depositional environment returned to normal oxygenated conditions, and palecoloured organic-poor limestones were deposited in unit 3 . The reason for this abrupt change is not fully understood, and further studies are needed to reconstruct the entire basin in order to constrain the palaeogeographic changes that occurred during and after the deposition of the 'black band'.

\section{Acknowledgements}

This study was supported financially by the Peri-Tethys Program and is a contribution to IGCP 343. We are indebted to Turkish Petroleum (TPAO) for help in the field. Richard Tyson and Paul Wignall are acknowledged for their critical suggestions on an earlier draft of this paper.

\section{Footnotes}

Present address: Université de Lille 1, Département des Sciences de la Terre, Bât. SN5, 59655 Villeneuve d'Ascq Cedex, France.

Present address: Laboratoire Sols et Environnement, INRA/ENSAIA-INPL, 2 av. de la Forêt de Haye, 54505 Vandoeuvre-lès-Nancy, France.

\section{References}

Baudin, F. \& Monod, O. ( 1996 ) L'évolution de la matière organique pour tester des reconstructions tectoniques. Exemple du Jurassique supérieur de la Formation d'Akkuyu (Taurus occidental, SW Turquie). Rev. Roum. Géol., 39 -40, 3548.

Baudin, F , Monod, O , Bégouën, V , Laggoun-Défarge, F. , Person, A. ( 1994 ) Caractérisation et diagenèse de la matière organique du Taurus occidental (Turquie méridionale). Reconstitution paléoenvironnementale et conséquences tectoniques. Bull. Soc. Géol. France, 165 , 135145.

Blumenthal, M. ( 1951 ) Recherches géologiques dans le Taurus occidental dans l'arrièrepays d'Alanya. Pub. MTA, Ankara, D5. 
Boussafir, M , Lallier-Vergès, E , Bertrand, P., Badaut-Trauth, D. ( 1994 ) Structure ultrafine de la matière organique dans des roches mères du Kimméridgien du Yorkshire (UK). Bull. Soc. Géol. France, 165 , 353361 .

Boussafir, M , Lallier-Vergès, E, Bertrand, P. , Badaut-Trauth, D. ( 1995 ) SEM and STEM studies on isolated organic matter and rock microfacies from a short-term organic cycle of the Kimmeridge Clay Formation (Yorkshire, UK) . In: Organic Matter Accumulation. The Organic Cyclicities of the Kimmeridge Clay Formation (Yorkshire, GB) and the Recent Maar Sediments (Lac Du Bouchet, France) (Ed. by E. Lallier-Vergès, N.P. Tribovillard and P. Bertrand), Lect. Notes Earth Sci., 57, 15-30.

Breit, G.N. \& Wanty, R.B. ( 1991 ) Vanadium accumulation in carbonaceous rocks: a review of geochemical controls during deposition and diagenesis. Chem. Geol., 91 , 8397.

Calvert, S.E. \& Pedersen, T.F. ( 1993 ) Geochemistry of Recent oxic and anoxic sediments: implications for the geological record. Mar. Geol., 113, 6788.

Claypool, G.E. \& Mancini, E.A. ( 1989 ) Geochemical relationships of petroleum in Mesozoic reservoirs to carbonate source rocks of Jurassic Smackover Formation, southwestern Alabama. AAPG Bull., 73 , 904924.

Corsin, P. \& Martin, C. ( 1969 ) Découverte d'un niveau à plantes dans un faciès marin du Malm, dans le Taurus occidental (Turquie). Ann. Soc. Géol. Nord, 89 , 335342.

Crusius, J , Calvert, S , Pedersen, T. , Sage, D. ( 1996 ) Rhenium and molybdenum enrichments in sediments as indicators of oxic, suboxic, and sulfidic conditions of deposition. Earth Planet. Sci. Lett., 145 , 6578.

Deuser, W.G. ( 1970 ) Carbon 13 in Black Sea and implications for the origin of hydrogen sulfide. Science, 168 , 15751577.

Dymond, J , Suess, E. , Lyle, M. ( 1992 ) Barium in deep-sea sediments: a geochemical proxy for paleoproductivity. Paleoceanography, $7,163181$.

Enay, R, Martin, C , Monod, O. , Thieuloy, J.P. ( 1971 ) Jurassique supérieur à Ammonites (Kimméridgien-Tithonique) dans l'autochtone du Taurus de Beysehir (Turquie méridionale) . In: Colloque Sur Jurassique Méditerranéen, Budapest, 1969. Ann. Inst. Geol. Publ, Hung., 54, 397-422.

Espitalié, J , Deroo, G. , Marquis, F. ( 1985a ) La pyrolyse Rock-Eval et ses applications. Rev. Inst. Fr. Pétrole, 40, 563579.

Espitalié, J , Deroo, G. , Marquis, F. ( 1985b ) La pyrolyse Rock-Eval et ses applications. Rev. Inst. Fr. Pétrole, 40 , 755784.

Espitalié, J , Deroo, G. , Marquis, F. ( 1986 ) La pyrolyse Rock-Eval et ses applications. Rev. Inst. Fr. Pétrole, $41,7389$.

Forey, P.L , Monod, O. , Patterson, C. ( 1985 ) Fishes from the Akkuyu Formation (Tithonian), Western Taurus, Turkey. Geobios, 18 , 195201. 
Gelin, F, Boussafir, M, Derenne, S , Largeau, C. , Bertrand, P. ( 1995 ) Study of qualitative and quantitative variations in kerogen chemical structure along a microcycle: correlation with ultrastructural features . In: Organic Matter Accumulation. The Organic Cyclicities of the Kimmeridge Clay Formation (Yorkshire, GB) and the Recent Maar Sediments (Lac Du Bouchet, France) (Ed. by E. Lallier-Vergès, N.P. Tribovillard and P. Bertrand). Lect. Notes Earth Sci., 57, 32-47.

Gingele, F. \& Dahmke, A. ( 1994 ) Discrete barite particles and barium as tracers of paleoproductivity in South Atlantic sediments. Paleoceanography, 9, 151168.

Gutnic, M , Monod, O , Poisson, A. , Dumont, J.-F. ( 1979 ) Géologie des Taurides occidentales. Mém. Soc. Géol. France, 137.

Ingall, E.D. \& van Cappellen, P. ( 1990 ) Relation between sedimentation rate and burial of organic phosphorus and organic carbon in marine sediments. Geochim. Cosmochim. Acta, 54 , 373386 .

Jones, R.W. ( 1984 ) Comparison of carbonate and shale source rocks . In: Petroleum Geochemistry and Source Rock Potential of Carbonate Rocks (Ed. by G. Palacas), AAPG Studies Geol., 18, 163-180.

Kumar, N , Anderson, R.F. , Biscaye, P.E. ( 1996 ) Remineralization of particulate authigenic trace metals in the Middle Atlantic Bight: implications for proxies of export production. Geochim. Cosmochim. Acta, 60 , 33833398.

de Leeuw, J.W. \& Sinninghe Damsté, J.S. ( 1990 ) Organic sulfur compounds and other biomarkers as indicator of paleosalinity. In: Geochemistry of Sulfur in Fossil Fuels (Ed. by W.L. Orr and C.M. White), ACS symposium series, 429, 417-443.

Lewan, M.D. ( 1986 ) Stable isotopes of amorphous kerogens from Phanerozoic sedimentary rocks. Geochim. Cosmochim. Acta, $50,15831591$.

Lichtfouse, E , Albrecht, P , Béhar, F. , Hayes, J.M. ( 1994 ) A molecular and isotopic study of the organic matter from the Paris Basin, France. Geochim. Cosmochim. Acta, $58,209221$.

McManus, J , Beulson, W.M , Klinkhammer, G.P , Kilgore, T.E. , Hammond, D.E. ( 1994 ) Remobilization of barium in continental margin sediments. Geochim. Cosmochim. Acta, 58 , 48994908.

Martin, C. ( 1969 ) Etude stratigraphique et tectonique d'une partie du Taurus au Nord d'Akseki (Turquie méridionale). Bull. Min. Res. Expl. Inst. Turkey, 72 , 110129.

Mongenot, T , Boussafir, M , Derenne, S , Lallier-Vergès, E , Largeau, C. , Tribovillard, N.-P. ( 1997 ) Sulphur-rich organic matter from bituminous laminites of Orbagnoux (France, Upper Kimmeridgian); the role of early vulcanization. Bull. Soc. Géol. France, 168 , 331342.

Monod, O. ( 1977 ) Recherches géologiques dans le Taurus occidental au sud de Beysehir (Turquie). Thesis, Université Paris-Sud. 
Morse, J.W. \& Mackenzie, F.T. ( 1990 ) Geochemistry of Sedimentary Carbonates. Developments in Sedimentology, 48, Elsevier, Amsterdam.

Oehler, J.H. ( 1984 ) Carbonate source rock in the Jurassic Smackover trend of Mississippi, Alabama, and Florida . In: Petroleum Geochemistry and Source Rock Potential of Carbonate Rocks (ed. by G. Palacas), AAPG Studies in Geol. , 18, 63-70.

Palacas, G.J , Anders, D.E. , King. J.D. ( 1984 ) South Florida basin. Prime example of carbonate source rock of petroleum . In: Petroleum Geochemistry and Source Rock Potential of Carbonate Rocks (Ed. by G. Palacas), AAPG Studies in Geol., 18, 71-96.

Permanyer, A , Baranger, R. , Lugardon, B. ( 1994 ) Oil shale characterisation in Messinian pre-evaporitic sediments from the Lorca Basin (SE-Spain) . In: Pétrologie Organique (Ed. by R. Curnelle and J.P. Sévérac), Bull. Centres Rech. Explor.-Prod. Elf-aquitaine, Spec. Publ. , 18, 136-149.

Raynaud, J.F , Lugardon, B. , Lacrampe-Couloume, G. ( 1988 ) Observation de membranes fossiles dans la matière organique 'amorphe' de roches mères de pétrole. C.R. Acad. Sci., 307 , 17031708.

Renard, M. ( 1986 ) Pelagic carbonate chemostratigraphy (Sr, $\left.\mathrm{Mg},{ }^{18} \mathrm{O},{ }^{13} \mathrm{C}\right)$. Mar. Micropal., 10,117164

Riboulleau, A, Baudin, F, Daux, V, Hantzpergue, P, Renard, M. , Zakharov, V. ( 1998 ). Evolution de la paléotempérature des eaux de la plate-forme russe au cours du Jurassique supérieur. C.R. Acad. Sci., 326, 239246.

Schmitz, B. ( 1987 ) Barium equatorial high productivity and the northward wandering of the Indian continent. Paleoceanography, 2, 6778.

Sinninghe Damsté, J.S , Ristra, W.I.C , Kock-Van Dalen, A.C , Leeuw, J.W. , Schenck, P.A. ( 1989 ) Quenching of labile functionalisable lipids by inorganic sulfur species: evidence for the formation of sedimentary organic sulfur compounds at the early stages of diagenesis. Geochim. Cosmochim. Acta, 53 , 13431356.

Taguchi, K. \& Mori, K. ( 1992 ) The distribution and generation of hydrocarbons in carbonate source rocks . In: Organic Matter. Production, Accumulation and Preservation in Recent and Ancient Sediments (Ed. by J.K. Whelan and J.W. Farrington), pp. 487-515, Columbia University Press, New York.

Tegelaar, E.W , de Leeuw, J.W , Derenne, S. , Largeau, C. ( 1989 ) A reappraisal of kerogen formation. Geochim. Cosmochim. Acta, $53,31033106$.

Tissot, B.P. \& Welte, D.H. ( 1984 ) Petroleum Formation and Occurrence, 2nd edn, Springer-Verlag, Berlin.

Turekian, K.K. \& Wedepohl, K.H. ( 1961 ) Distribution of the elements in some major units of the Earth's crust. Geol. Soc. Am. Bull., 72 , 175191. 
Van Cappellen, P. \& Ingall, E.D. ( 1994 ) Benthic phosphorus regeneration, net primary production and ocean anoxia: a model of the coupled marine biogeochemical cycles of carbon and phosphorus. Paleoceanography, 9 , 677692.

Wanty, R.B. \& Goldhaber, M.B. ( 1992 ) Thermodynamics and kinetics of reactions involving vanadium in natural systems: accumulation of vanadium in sedimentary rock. Geochim. Cosmochim. Acta, 56, 14711483.

Weissert, H. \& Mohr, H. ( 1996 ) Late Jurassic climate and its impact on carbon cycling. Palaeogeogr., Palaeoclimatol., Palaeoecol., 122, 2743.

\section{Figures}

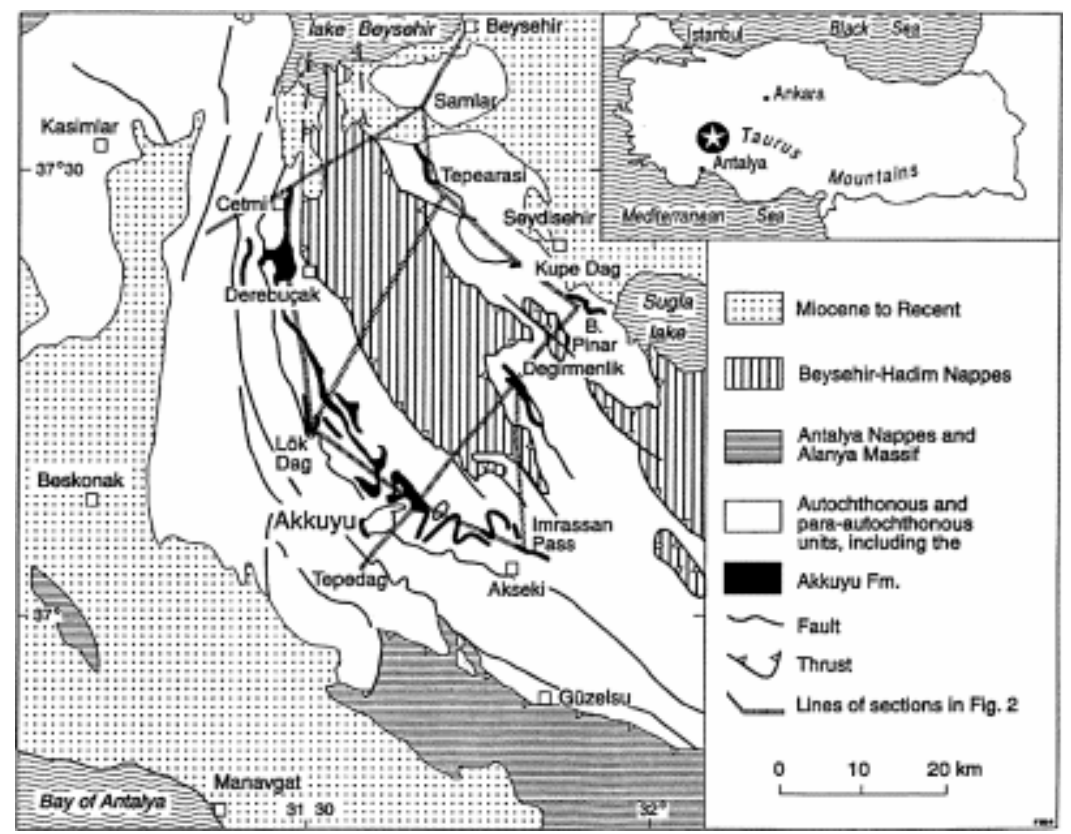

Fig. 1. Simplified geological map of the central part of the western Taurus and location of the studied section. 


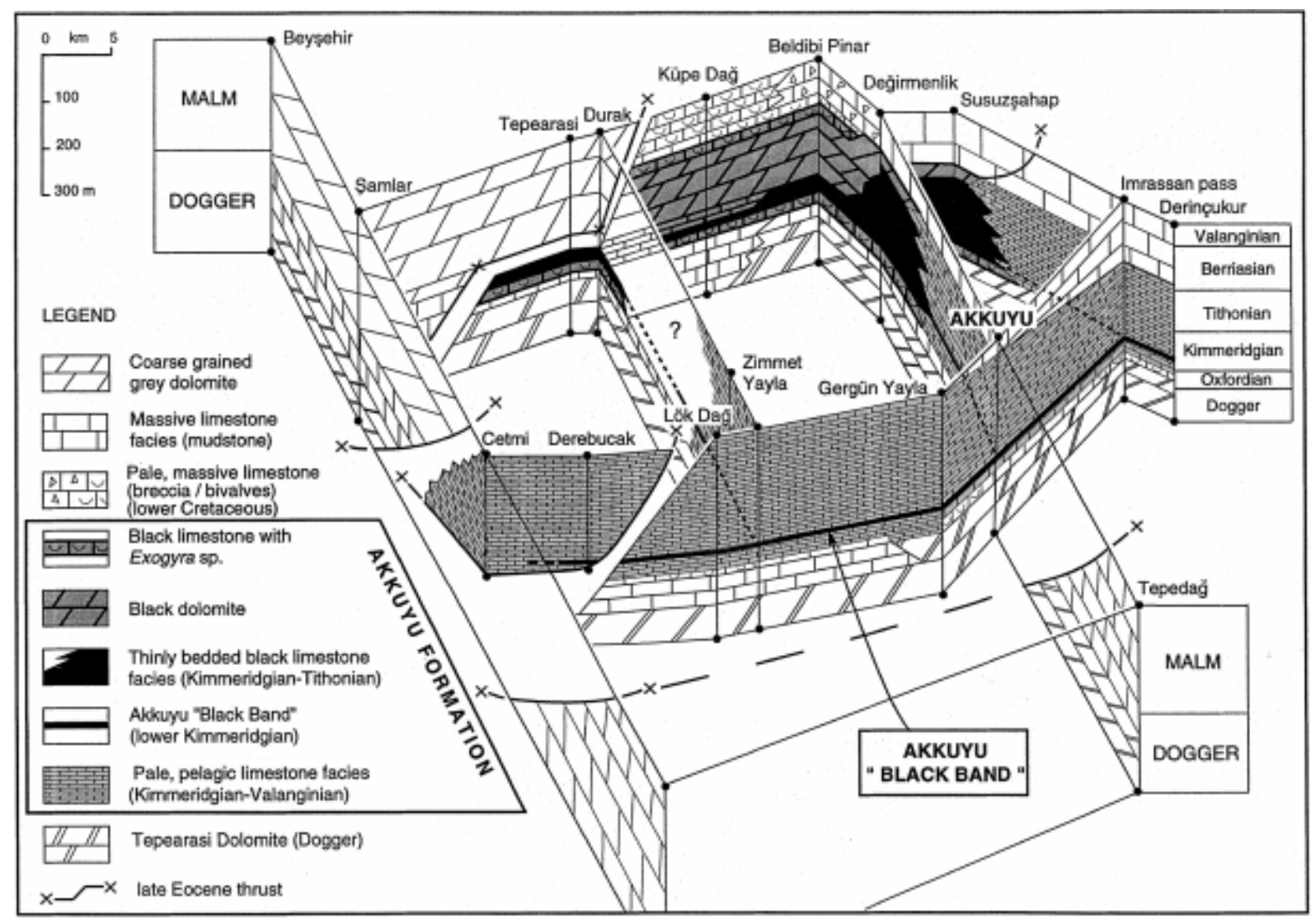

Fig. 2. Three-dimensional restoration of the present geometry of the Akkuyu Basin showing the spatial distribution of facies for the Upper Jurassic to Upper Cretaceous. 

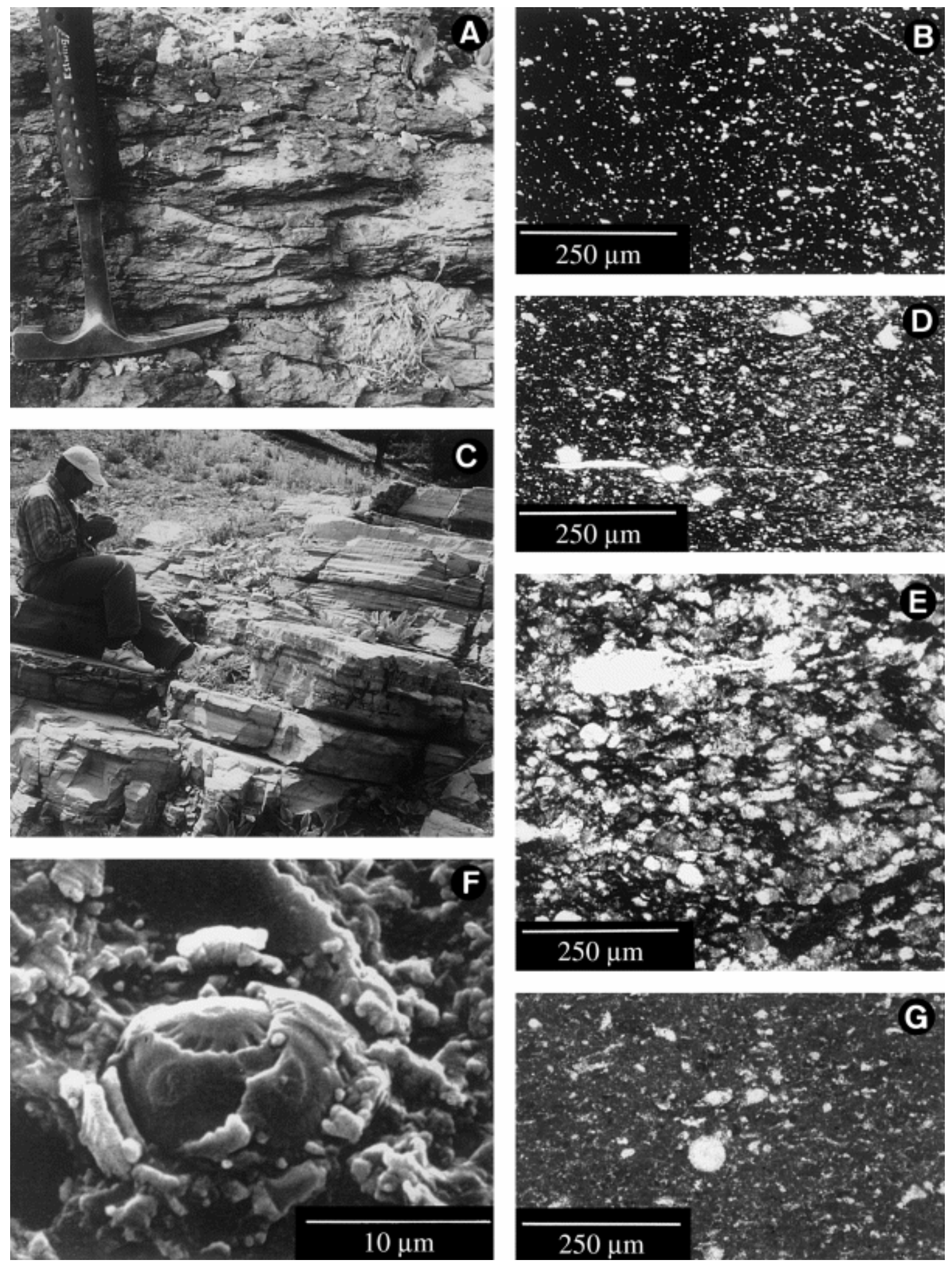

Fig. 3. Field photographs and photomicrographs of thin sections from the different units of the 'black band' of the Akkuyu Formation. (A) Close-up view of the black marlstone of unit 1 (hammer is $30 \mathrm{~cm}$ long). (B) Thin section of sample AK76 (unit 1). (C) Succession of black limestone of unit 2. (D) Thin section of sample IC (unit 2). (E) Thin section of sample IE 
showing the packstone texture of the sediment. (F) Coccosphere within black limestone of unit 2. (G) Thin section of sample AK 123 (unit 3 ).

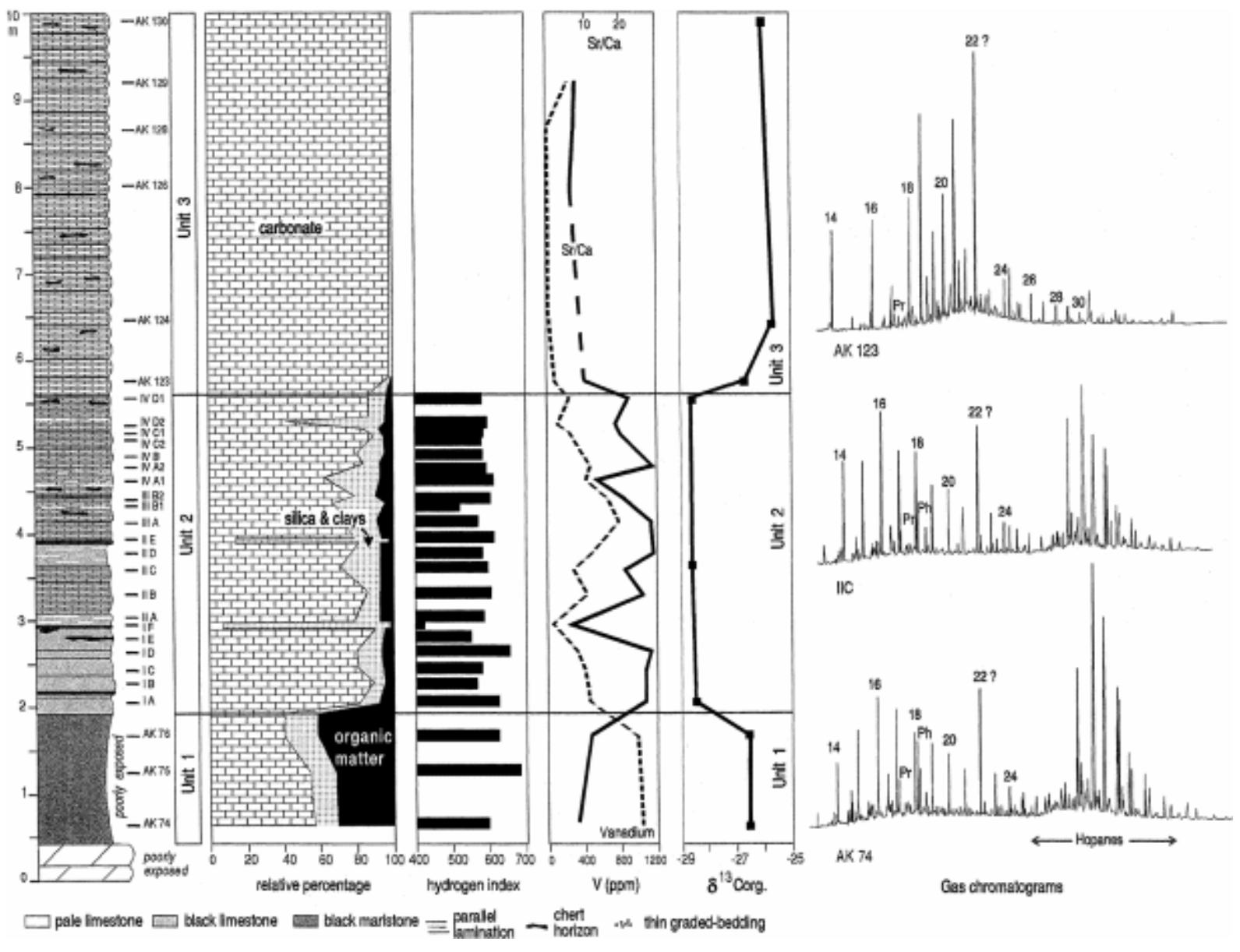

Fig. 4. Schematic section, bulk mineralogy, selected organic and inorganic geochemical parameters of the 'black band' of the Akkuyu Formation. Pr, pristane; Ph, phytane; numbers refer to $n$-alkane carbon number. 

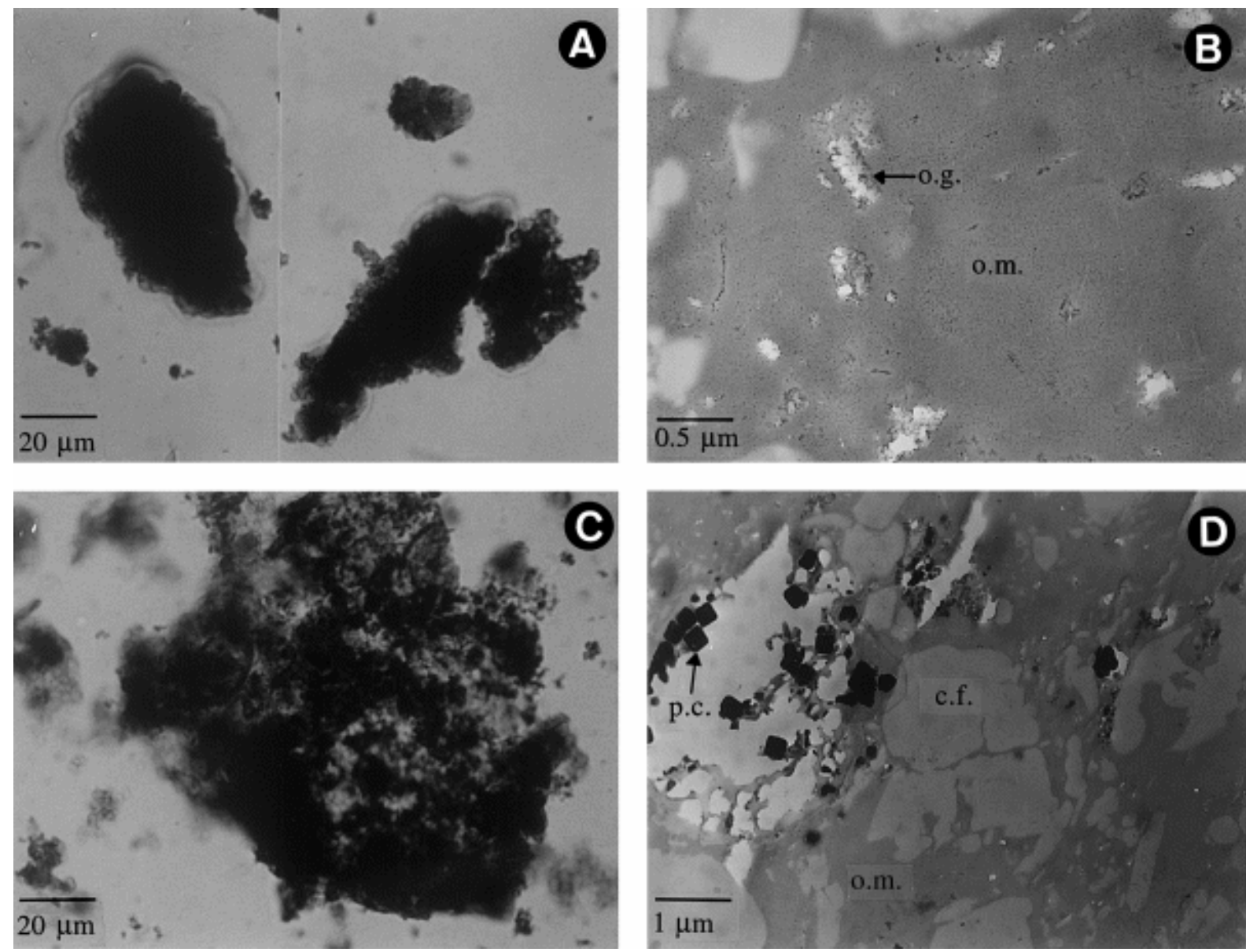

Fig. 5. Photomicrographs of palynofacies and ultrastructure (TEM) of the amorphous organic matter from the Akkuyu Formation. (A and B) Sample AK74. (C and D) Sample IIC. cf, carbon film; o.m., organic matrix; o.g., osmium granule caused by Os tetroxide fixation; p. c., pyrite crystals. Note that EDX analyses of these two types of AOM indicate the occurrence of $\mathrm{C}$ and $\mathrm{S}$.

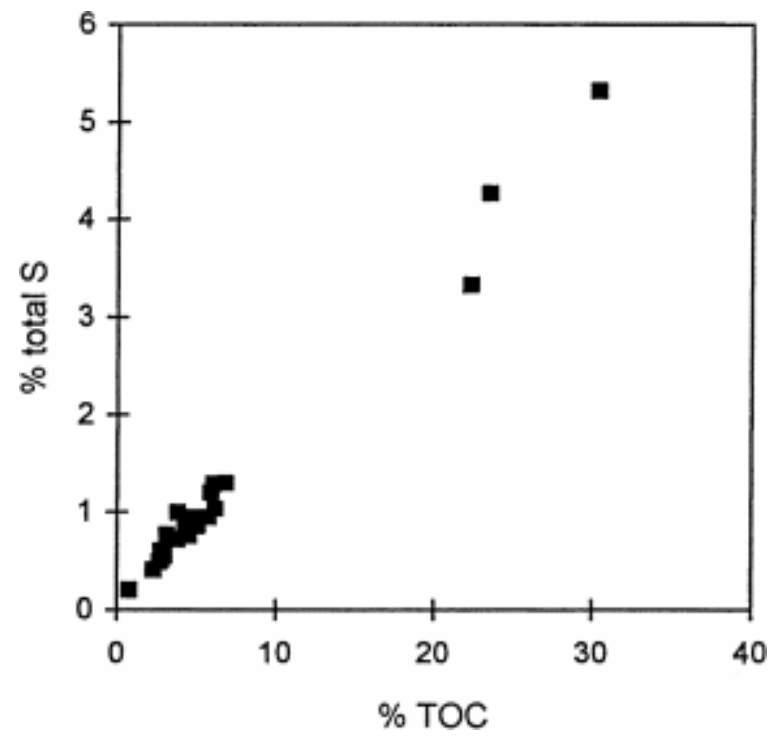

Fig. 6. TOC vs. total S cross-plot showing the strong relationship $(r=0.993)$ between organic carbon and total sulphur contents. 

Tables

\begin{tabular}{|c|c|c|c|c|c|c|c|}
\hline \multirow[b]{2}{*}{ Sample } & $\mathrm{CaCO}_{3}$ & S & TOC & \multirow{2}{*}{$\begin{array}{l}T_{\max } \\
\left({ }^{\circ} \mathrm{C}\right)\end{array}$} & \multirow{2}{*}{$\begin{array}{l}\text { HI } \\
\text { (mg HC/g TOC) }\end{array}$} & \multirow{2}{*}{$\begin{array}{l}\text { OI } \\
\text { (mg CO } 2 / g \text { TOC) }\end{array}$} & \multirow{2}{*}{$\begin{array}{l}\delta^{13} \mathrm{C} \\
(\% \text { PDB }\end{array}$} \\
\hline & & $(\%)$ & & & & & \\
\hline \multicolumn{8}{|l|}{ Unit 3} \\
\hline AK 130 & 98 & ND & $<0.1$ & ND & ND & ND & $-26 \cdot 04$ \\
\hline AK 129 & 99 & 0.00 & $<0 \cdot 1$ & ND & ND & ND & $-21 \cdot 74$ \\
\hline AK 128 & 98 & 0.07 & $<0.1$ & ND & ND & ND & ND \\
\hline AK 126 & 99 & 0.01 & $<0.1$ & ND & ND & ND & ND \\
\hline AK 124 & 98 & 0.08 & $<0.1$ & ND & ND & ND & $-25 \cdot 68$ \\
\hline AK 123 & 98 & 0.00 & $<0.1$ & ND & ND & ND & $-26 \cdot 68$ \\
\hline \multicolumn{8}{|l|}{ Unit 2} \\
\hline IV D1 & 87 & $0 \cdot 49$ & $2 \cdot 69$ & 435 & 576 & 9 & $-28 \cdot 55$ \\
\hline IV D2 & 42 & $0 \cdot 41$ & $2 \cdot 34$ & 434 & 589 & 8 & ND \\
\hline IV C1 & 84 & 0.94 & $5 \cdot 79$ & 433 & 580 & 7 & ND \\
\hline IV C2 & 90 & $0 \cdot 71$ & $3 \cdot 80$ & 433 & 574 & 8 & ND \\
\hline IV B & 81 & $0 \cdot 76$ & $3 \cdot 13$ & 434 & 578 & 9 & ND \\
\hline IV A2 & 84 & $0 \cdot 87$ & $5 \cdot 10$ & 434 & 587 & 7 & ND \\
\hline IV A1 & 63 & 0.94 & $4 \cdot 83$ & 433 & 606 & 7 & ND \\
\hline III B2 & 79 & $1 \cdot 30$ & $6 \cdot 87$ & 434 & 598 & 6 & ND \\
\hline III B1 & 68 & 0.51 & $2 \cdot 79$ & 432 & 518 & 20 & ND \\
\hline III A & 79 & 1.03 & $6 \cdot 22$ & 435 & 566 & 8 & ND \\
\hline II E & 14 & $0 \cdot 49$ & $2 \cdot 70$ & 430 & 608 & 12 & ND \\
\hline II D & 81 & 0.85 & 4.99 & 431 & 578 & 11 & ND \\
\hline II C & 71 & $0 \cdot 83$ & $4 \cdot 32$ & 434 & 591 & 8 & $-28 \cdot 49$ \\
\hline II B & 86 & $0 \cdot 76$ & 4.54 & 433 & 600 & 12 & ND \\
\hline II A & 78 & 1.20 & $5 \cdot 93$ & 433 & 580 & 10 & ND \\
\hline I F & 7 & $0 \cdot 20$ & $0 \cdot 81$ & 428 & 432 & 56 & ND \\
\hline I E & 90 & 0.55 & $2 \cdot 98$ & 433 & 547 & 11 & ND \\
\hline I D & 80 & $0 \cdot 87$ & $4 \cdot 44$ & 433 & 647 & 9 & ND \\
\hline I C & 81 & 0.99 & $3 \cdot 84$ & 435 & 574 & 17 & ND \\
\hline I B & 89 & 0.60 & $2 \cdot 80$ & 434 & 561 & 12 & ND \\
\hline I A & 80 & $1 \cdot 30$ & $6 \cdot 12$ & 435 & 619 & 11 & $-28 \cdot 42$ \\
\hline \multicolumn{8}{|l|}{ Unit 1} \\
\hline 93AK 76 & 40 & $5 \cdot 32$ & $30 \cdot 36$ & 434 & 618 & 8 & $-26 \cdot 51$ \\
\hline $93 \mathrm{AK} 75$ & 55 & $4 \cdot 27$ & $23 \cdot 50$ & 436 & 674 & 7 & ND \\
\hline 93AK 74 & 57 & $3 \cdot 33$ & $22 \cdot 33$ & 433 & 590 & 14 & $-26 \cdot 45$ \\
\hline
\end{tabular}

$\mathrm{ND}=$ not determined. 
Table 1. Carbonate, total sulphur (S) and total organic carbon (TOC) contents of the 'black band' (units 1 and 2) and overlying pale-coloured limestones (unit 3) of the Akkuyu Formation, plus Rock-Eval data on whole-rock and $\delta^{13} \mathrm{C}$ values of selected kerogen concentrates.

\begin{tabular}{|c|c|c|c|c|c|c|c|c|c|c|c|c|c|c|c|c|c|c|c|c|}
\hline \multirow[b]{2}{*}{ Sample } & $\mathrm{Ca}$ & $\mathrm{Fe}$ & $\mathrm{Al}$ & K & Th & $\mathrm{Sr}$ & $\mathrm{Mn}$ & $\mathrm{Ni}$ & $\mathrm{Cu}$ & $\mathrm{V}$ & Mo & $\mathrm{Cr}$ & $\mathrm{Ba}$ & P & $\mathrm{Fe} / \mathrm{A}$ & $1 \mathrm{~K} / \mathrm{Al}$ & $\mathrm{Th} / \mathrm{Al}$ & IlV/Al & $\mathrm{P} / \mathrm{Al}$ & $\mathrm{Sr} / \mathrm{Ca}$ \\
\hline & \multicolumn{4}{|c|}{ (\%) } & \multicolumn{10}{|c|}{ (p.p.m.) } & \multicolumn{6}{|c|}{ (element ratio) } \\
\hline \multicolumn{21}{|l|}{ Unit 3} \\
\hline & $24 \cdot 0$ & 0.08 & $0 \cdot 18$ & $0-09$ & 0.5 & 186 & 9 & 14 & 6 & 240 & 6 & 13 & 10 & 190 & $0 \cdot 4$ & $0 \cdot 5$ & 3 & 1334 & 1056 & $7 \cdot 8$ \\
\hline AK 128 & $33 \cdot 2$ & 0.01 & 0.02 & 0-01 & ND & 237 & 4 & 5 & ND & 9 & 2 & 12 & 3 & 65 & $0 \cdot 6$ & 06 & ND & 486 & 3509 & $7 \cdot 1$ \\
\hline AK 126 & $31 \cdot 6$ & 0.03 & $0 \cdot 01$ & $0-01$ & $1 \cdot 0$ & 198 & 11 & 4 & 1 & 9 & 1 & 6 & 2 & 161 & $1 \cdot 9$ & 1.0 & 118 & 1063 & 19013 & $6 \cdot 3$ \\
\hline AK 124 & $28 \cdot 8$ & 0.03 & 0.03 & $0-03$ & $1 \cdot 1$ & & & 6 & 5 & 12 & 1 & 10 & 4 & 151 & $1 \cdot 1$ & $1 \cdot 1$ & 42 & 453 & 5706 & ND \\
\hline AK 123 & $32 \cdot 0$ & $0 \cdot 05$ & $0 \cdot 08$ & $0-05$ & $1 \cdot 3$ & 308 & 8 & 29 & 70 & 75 & 1 & 37 & 8 & 158 & $0 \cdot 6$ & 06 & 16 & 945 & 1990 & 96 \\
\hline \multicolumn{21}{|l|}{ Unit 2} \\
\hline & $34 \cdot 8$ & 0.12 & $0 \cdot 31$ & $0-22$ & $0-6$ & 771 & 15 & 130 & 10 & 226 & 22 & 40 & 15 & 191 & $0 \cdot 4$ & 07 & 2 & 736 & 622 & $22 \cdot 2$ \\
\hline IV D2 & $16 \cdot 8$ & 0.07 & $0 \cdot 19$ & $0 \cdot 10$ & 0.8 & 303 & 9 & 654 & 9 & 118 & 18 & 10 & 14 & 196 & $0 \cdot 4$ & 05 & 4 & 637 & 1058 & $18 \cdot 0$ \\
\hline & 36.0 & 0.12 & $0 ; 33$ & $0 \cdot 22$ & $1 \cdot 2$ & 709 & 17 & 95 & 13 & 238 & 28 & 39 & 12 & & $0 \cdot 4$ & 0.7 & 4 & 725 & 640 & $19 \cdot 7$ \\
\hline IV A2 & $33 \cdot 6$ & 0.25 & 0559 & $0: 36$ & $2 \cdot 4$ & 959 & 17 & 139 & 19 & 471 & 39 & 68 & 23 & 330 & $0 \cdot 4$ & 0.6 & 4 & 802 & 562 & $28 \cdot 5$ \\
\hline IV A1 & $25 \cdot 2$ & 0.20 & 0.49 & 0.28 & $1 \cdot 4$ & 332 & 12 & 304 & 20 & 424 & 43 & 86 & 22 & 24 & $0 \cdot 4$ & 0.6 & 3 & 71 & 665 & $13 \cdot 2$ \\
\hline IIII B2 & $31 \cdot 6$ & $0: 34$ & $0 \cdot 70$ & $0: 49$ & $2 \cdot 0$ & 682 & 16 & 161 & 27 & 658 & 52 & 91 & 39 & 26 & 0.5 & 0.7 & 3 & 935 & 463 & 216 \\
\hline IIII A & $31 \cdot 6$ & $0 \cdot 36$ & 0.73 & 0.50 & 18 & 887 & 17 & 154 & 28 & 778 & 52 & 77 & 32 & 283 & 0.5 & 0.7 & 2 & 1073 & 390 & $28 \cdot 1$ \\
\hline II D & $32 \cdot 4$ & $0 \cdot 35$ & 0.79 & 0.58 & $2 \cdot 3$ & 925 & 17 & 170 & 22 & 504 & 34 & 55 & 34 & 350 & $0-4$ & 0.7 & 3 & 635 & 441 & $28 \cdot 5$ \\
\hline II C & $28 \cdot 4$ & $0 \cdot 11$ & $0 \cdot 32$ & 0.23 & $1 \cdot 2$ & 591 & 13 & 186 & 15 & 280 & 32 & 17 & 13 & 204 & $0 \cdot 3$ & 0.7 & 4 & 867 & 632 & $20 \cdot 8$ \\
\hline II B & $34 \cdot 4$ & 0.21 & $0-51$ & 0.33 & $1 \cdot 7$ & 882 & 17 & 109 & 16 & 433 & 29 & 56 & 21 & 233 & $0-4$ & 06 & 3 & 843 & 454 & $25 \cdot 6$ \\
\hline IF & $2 \cdot 8$ & 0.07 & $0 \cdot 15$ & 0.06 & $0-5$ & 18 & 3 & 2 & 13 & 31 & 4 & 198 & 6 & 88 & $0 \cdot 5$ & $0 \cdot 4$ & 3 & 209 & 594 & $6 \cdot 4$ \\
\hline ID & $32 \cdot 0$ & 0.28 & 0.65 & $0 \cdot 45$ & 1.8 & 898 & 19 & 151 & 16 & 328 & 25 & 74 & 31 & 283 & $0 \cdot 4$ & 0.7 & 3 & 508 & 438 & $28 \cdot 1$ \\
\hline IC & $32 \cdot 4$ & 0.38 & 0.85 & 0.60 & $2 \cdot 3$ & 854 & 19 & 146 & 16 & 424 & 31 & 28 & 37 & 276 & $0 \cdot 4$ & $0 \cdot 7$ & 3 & 501 & 326 & $26 \cdot 4$ \\
\hline IA & $32 \cdot 0$ & $0 \cdot 36$ & 0.93 & 0.55 & $1 \cdot 7$ & 850 & 18 & 144 & 22 & 466 & 46 & 88 & 29 & 444 & $0 \cdot 4$ & $0 \cdot 6$ & 2 & 503 & 479 & $26 \cdot 6$ \\
\hline \multicolumn{21}{|l|}{ Unit 1} \\
\hline $93 \mathrm{AK} 76$ & $16 \cdot 0$ & 0.51 & 0.92 & $0 \cdot 62$ & ND & 183 & 17 & 196 & 41 & 991 & 73 & 248 & 36 & 409 & $0 \cdot 6$ & $0 \cdot 7$ & ND & 1082 & 447 & $11 \cdot 4$ \\
\hline $93 \mathrm{AK} 74$ & $22 \cdot 8$ & 0.61 & $0-91$ & 0.81 & ND & 177 & 17 & 231 & 46 & 1022 & 100 & 278 & 37 & 414 & $0 \cdot 7$ & $0 \cdot 9$ & ND & 1129 & 457 & 7.8 \\
\hline Average carbonate & $31 \cdot 0$ & ND & 0.40 & ND & ND & ND & 1100 & 20 & 4 & 20 & $0 \cdot 4$ & 11 & 10 & 400 & ND & ND & ND & 48 & 952 & ND \\
\hline
\end{tabular}

Table 2. Major and trace elements of the 'black band' (units 1 and 2) and overlying pale-coloured limestones (unit 3) of the Akkuyu Formation. 